\title{
MULTIPLE PERSONALITY IN VENOM MOVIE SCRIPT BY JEFF PINKNER ET.AL.
}

\author{
Lazuardi Akbar, Safitri Hariani \\ Faculty of Literature \\ Universitas Islam Sumatera Utara (UISU), Medan, Indonesia \\ E-mail: lazuardiakbar80@gmail.com
}

Received: 2021-04-27

Accepted: 2021-05-24

\begin{abstract}
This study constitutes an analysis of the Multiple Personalities in Venom Movie. This analysis describes the multiple personalities which occur on Eddie Brock as the first character of the movie. The data are obtained from the script of the movie which is analyzed in the discussion of this study. The writers adopts the theory of multiple personality with a concept of disruption in memory and identity of a person. Multiple personality is also termed Dissociative Identity Disorder, disorder marked by the change of individual feeling concerning identity, memory or conscious. An individual gets difficulty in recollecting important events of himself in the past, forgetting his identity even forming his new identity. The whole study is conducted by descriptive qualitative design, classifying the obtained data in two sub topics. The first is about the first cahracter as a journalist, and the second is about the first character as venom. As a journalist, he is weak, fearful and kind, but as venom, he is strong, brave and evil. The research result shows clearly that the first character, Eddie Brock in Venom movie written by Jeff Pinkner et. al. has multiple personalities.
\end{abstract}

Keywords: Multiple Personality, Journalist, Venom, Movie.

\section{Introduction}

Literary work is the result of the activity of the author in producing a literary work that is closely related to psychological phenomena because the author displays the psychological aspects through characters. Literary works are able to depict human psychology, although the authors present them in fiction. Fiction is the result of imagination, the imagination of the author through the function of literary works in which we can find out the psychological aspects of human problems.

Personality is an inseparable part of everyone, born with different personalities. There are rare cases where a person has more than one personality or can be said to have multiple personalities. In scientific language, multiple personality is called Dissociative Identity Disorder and is a psychological disease.

In examining the psychological aspects of the main character in a story the writers use the theory of psychoanalysis. Psychoanalysis is a scientific discipline that was started around the 1900s by Sigmund Freud. The theory of psychoanalysis is related to the function and mental development of humans. This science is a part of 
psychology that has made a major contribution and has been made for human psychology so far (Minderop, 2013: 11). There are many famous figures of world psychoanalysis including Sigmund Freud, Carl Jung, Lacan etc. Sigmund Freud is the first person in psychoanalysis. He is also called the father of psychoanalysis. Sigmund Freud bravely explains directly the process of creating art as a result of pressures and heaps of problems in the subconscious which are then sublimated in the form of artistic creation. The psychoanalysis approach refers to many of Freud's theories. There are id, superego, and ego in humans which cause people to always be in a state of war in them, restless and agitated. But if all the three work in balance they will show a reasonable character (Endraswara, 2003: 196-197).

Venom is a movie which tells the story of Eddie Brock (Tom Hardy), a journalist who questions a case that is avoided by the government, which leads him to investigate the Life Foundation Company run by Carlton Drake (Riz Ahmed). The company owns an alien symbiosis. The symbiotic figure finally looks for a new parent, namely the journalist Eddie Brock. After this happens to him, Eddie Brock seems to have multiple personalities inside his body and mind. Multiple personality is a condition in which a person has two or more different personalities. Multiple personality is also called dissociative identity disorder, and is generally caused by traumatic experiences that occur repeatedly in childhood. People with multiple personalities have two or more personalities in him, which are different from each other or even contradictory. One personality can take over control of the body and mind of the people with multiple personalities at any time, and is usually triggered by certain situations when the people feel stressed, fearful, or angry. As a journalist, Eddie Brock belongs to the weak, fearful but good person, but as Venom, he becomes strong, brave and evil. Thus, his personality changes after he turns to Venom.

The writers use the theory of Davidson \& Neale in Widury \& Fausiyah (2006:104) considered very suitable in analyzing multiple personality experienced by Eddie Brock.

\section{Literature Review}

The word "personality" is derived from the Greek, namely "persona" which means "a mask", the mask worn by actors on the stage from the Greek theatre. The word persona is usually worn by the performer during ancient times to portray a form of behavior and personal character. According to Funder (1997), personality refers to individual characteristic patterns of thought, emotion, and behavior that determine unique adjustments to the environment. It means that personality is the unique combination of patterns that influence behavior, thought, motivation, and emotion in human being. Basically, we are the same, we all have the same human nature, all of human bodies and human minds, we all have human thoughts and human feelings (Smith, 2004).

Lundberg (2010) states that personality refers to the habits, attitudes and other social traits that are characteristics of a given individual's behavior. In short, personality is pattern of habits, traits, attitudes and ideas of an individual. While Freud (1994) explains that personality is an individual's characteristic pattern of thinking, feeling and acting that persist over time and in different situations. Personality is an expression in many ways from overt thought and feeling (Walter et.al, 2004). Moreover, according to Adam Smith (1971), personality is something abstract based on inferences derived from behavior of likes and dislike, fears and virtues, strengths and weakness. The personality 
term is used by the experts to indicate an attribute of an individual, or to describe what, why and how humans behave. Basically, it can be concluded that everybody in this world has different personality. From their behavior, it can be seen that pattern of thoughts, feelings, social adjustments and behavior consistently exhibited over time that strongly influences one's expectations, self-perceptions, values and attitudes.

In scientific language, multiple personality is called Dissociative Identity Disorder It includes disruption in memory and identity of a person. Dissociative Identity Disorder is disorder marked by the change of individual feeling concerning identity, memory or conscious. An individual gets difficulty in recollecting important events of himself in the past, forgetting his identity even forming his new identity (Widuri and Neale, 2006:39)

Dissociative identity disorder can also be regarded as the thought to be a complex psychological condition that is likely caused by many factors, including severe trauma during early childhood (usually extreme, repetitive physical, sexual, or emotional abuse). It is a severe form of dissociation, a mental process which produces a lack of connection in a person's thoughts, memories, feelings, actions, or sense of identity.

Rob and Carolyn Spring (2010) describe that the symptoms of dissociative identity disorder are of different types including varying degrees of the following five core dissociative identity disorder symptoms: Amnesia (This will be for specific and significant blocks of time that have passed), Depersonalization (This is a feeling of being detached from yourself or looking at yourself almost from the outside, as an observer would. It can also include feeling cut-off from parts of your body or detached from your emotions), Derealisation (This is a feeling of detachment from the world around you, or a sense that people or things feel unreal), Identity confusion (This is a feeling of internal conflict of who you are having difficulty in defining yourself), Identity alteration (This is a shift in identity accompanied by changes).

It can be stated that an individual with such disorders finds difficulty to remember important events, forget the identity and form a new identity. This dissociative disorder appears because of traumatic events and generally used as self defense to face the traumatic events.

\section{Research Method}

In carrying out this research, the writers use descriptive qualitative method in which the qualitative data collected are analyzed and interpreted descriptively. This method will help the writers analyze the obstacle found in the movie script. As stated by Bogdan and Biklen (2012) that qualitative is descriptive, the data are in the forms of word or phrases and also the picture rather than number. In this case, the writers verify the data by listing the fact describing the multiple personality of the main character, Eddie Brock.

The data taken are in the forms of words, phrases and sentences. In collecting the data, the writers use several steps:

1. Watching the Venom movie repeatedly.

2. Understanding the movie.

3. Finding out the data related to the research problems.

4. Taking notes.

5. Dividing the data into several parts based on the classifications of discussions. 


\section{Discussion}

\subsection{As Journalist}

In the movie, Eddie Brock as the main character works as a journalist. However, he is later fired for investigating Life Foundation. Brock then meets again with a Life Foundation scientist. He investigates the company until he becomes Venom. Actually he is a kind man. He wants to help other people. In doing his job as a journalist, sometimes he feels fearful in facing the danger because it can endanger his life. He is also weak. These three personalities such as weakness, fearfulness, and kindness are in Brock s when he is not venom.

\subsubsection{Weakness}

Various investigations are carried out by Eddie to find out what really happens with the science developed by Life Foundations. Unfortunately, Brock's efforts always fail, until one day, Eddie finds something strange and terrible at the same time. An organic cell called Symbiote makes him curious. On the one hand, Dr. Carlton does want this Symbiote to be revealed. Symbiote is a kind of parasite that sticks to the body it inhabits. The symbiote is named Venom. It fuses with Eddie's body, giving him immense power and turning him into a superhuman. But when the symbiote does not stick with Eddie's body, he becomes weak, it can be seen in the scripts below:

\begin{tabular}{|c|c|}
\hline TREECE & : Eddie, Eddie, Eddie \\
\hline EDDIE & : You can kill me,' cause I'm dying anyway. \\
\hline TREECE & $\begin{array}{l}\text { : I'm not just gonna kill you, That would't be any fun. } \\
\text { No, no, no. I'm gonna rip your tongue out of your } \\
\text { face. Whoo! }\end{array}$ \\
\hline (GRUNTS) & \\
\hline DRAKE & $\begin{array}{l}\text { : Stop. You're bleeding all over my lab. Go. Go! } \\
\text { Where is he? }\end{array}$ \\
\hline EDDIE & $\begin{array}{l}\text { : I don't know. And you know what? Even if I did, I } \\
\text { wouldn't tell you anyway. I don't trust you, and } \\
\text { you're insane. }\end{array}$ \\
\hline DRAKE & : That hurts. \\
\hline Eddie & : Sorry. \\
\hline DRAKE & $\begin{array}{l}\text { : Long journal entry about that tonight. You're being } \\
\text { dumb, Brock. I'm not insane. What's insane is the } \\
\text { way humans choose to live today. Think about it. All } \\
\text { we do is take, take, take. It can't go on. We've } \\
\text { brought the planet to the brink of extinction. We're } \\
\text { parasites. You're good example. Think about it. All } \\
\text { you do is take. You took my Symbiote. You take } \\
\text { potshots at a great man, trying to get something } \\
\text { done. }\end{array}$ \\
\hline EDDIE & : Who? \\
\hline DRAKE & $\begin{array}{l}\text { : Didn't you take from the person you loved the most, } \\
\text { That's insane. What I've initiated is a whole new } \\
\text { world, a new species. Man and Symbiote combined. }\end{array}$ \\
\hline EDDIE & $\begin{array}{l}\text { : Let me tell you something, buddy. All right? Just man } \\
\text { to man. Because I have spent a significant amount of }\end{array}$ \\
\hline
\end{tabular}




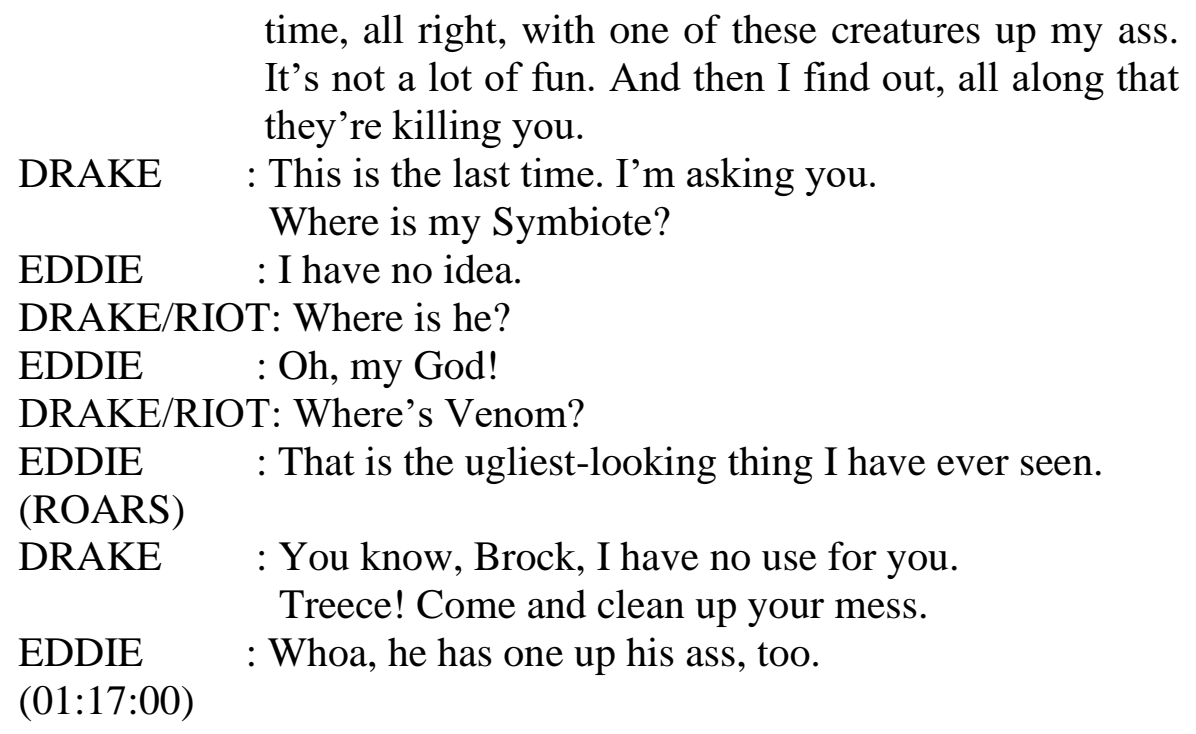

The script below shows that Eddie Brock becomes weak because Venom has been separated from Brock's body. And he is forced to walk by Treece through the wilderness at that time and he has kicked to the ground and he has almost been killed with a gun. But he survives because he is found by Anne Weying, who becomes Venom's form. From the script, it shows that Eddie Brock needs other people to help him when the venom does not stick in his body. He becomes a weak person and cannot fight those who are mean to him.

$\begin{array}{ll}\text { EDDIE } & \text { : Yeah, what you gonna do, you gonna walk me to } \\ & \text { death? } \\ \text { TREECE } & \text { : Shut up. } \\ & \text { Not so tough without your friend. (COCKS PISTOL) } \\ \text { EDDIE } & \text { : Did your mama not love you? (GRUNTING) } \\ & \text { God damn it! (GRUNTS) (INHALES SHARPLY) I } \\ & \text { guess it pays to be a specialist, huh? You know, it } \\ & \text { doesn't matter if you kill me anyway. Because there's } \\ & \text { something } \\ & \text { way bigger afoot in this world than you and me. Much } \\ & \text { bigger than you. } \\ & \text { Karma's a bitch. } \\ \text { TREECE } \quad \text { I don't believe in karma. (CRUNCHING) } & (01: 17: 00)\end{array}$

\subsubsection{Fearfulness}

As a journalist, Eddie Brock also has another personality besides being weak. He is also afraid of something. It can be seen in the script below when Eddie Brock is in his apartment suddenly Cartlon Drake's men come to meet him and would arrest Eddie Brock who already has a symbiote / venom. Then Treece asks Eddie Brock about the symbiote and asks him to return the symbiote. Then suddenly Drake's men point the gun at Eddie's body which causes Eddie feels worried / fear for his life because he wants to be shot by a gun belonging to Carlton Drake's men. At this time, Drake is only a journalist. He is only an ordinary person. From the explanation above it is clear that 
when he in in his journalist form, he has a fear of worrying about Drake's men. Look at the following script:

\begin{tabular}{|c|c|}
\hline Drake Guard & : Hey Eddie. \\
\hline Venom & : Who the hell is this guy? \\
\hline $\begin{array}{l}\text { Drake Guard } \\
\text { (GUNS POWERINC }\end{array}$ & $\begin{array}{l}\text { : I'm gonna need Mr.Drake' property back. } \\
\text { J UP) }\end{array}$ \\
\hline Eddie Brock & : Whoa. \\
\hline Venom & : What are you doing? \\
\hline Eddie Brock & : I'm uh... I'm putting my hands up. \\
\hline $\begin{array}{l}\text { VENOM } \\
\text { (STRAINING) }\end{array}$ & : You are making us look bad. \\
\hline Eddie Brock & : No, I am not. \\
\hline VENOM & : Yes, you are. \\
\hline VENOM & : Why would you do that? \\
\hline Eddie Brock & : 'Cause it is a very sensible thing to that? \\
\hline Drake Guard & : Eddie... \\
\hline VENOM & : I will take care of this myself. \\
\hline
\end{tabular}

(59: 14)

The following scripts show that Eddie Brock tells his feelings to Anne Weying. She is his ex-girlfriend. He feels afraid of his life when he is transformed into Venom. He feels worried about his life that does not work like other normal humans. Then he shares this to Anne and complains about his current life. It is clear that Eddie Brock looks fearful when he turns into Venom.

\begin{tabular}{|c|c|}
\hline EDDIE BROCK & : Annie! Annie, wait! Wait please. \\
\hline Anne Weying & : Oh, what the hell is that? \\
\hline Eddie Brock & : That's not me. I've been infected. \\
\hline Anne Weying & : Eddie, what's happening? \\
\hline Eddie Brock & : He's inside me. \\
\hline Anne Weying & : “He”? \\
\hline Eddie Brock & : Yes. I know it sound crazy, but... \\
\hline Anne Weying & : You're sick. Eddie, you're really sick. \\
\hline Eddie Brock & : No, I am scared! \\
\hline EDDIE Brock & : And I need help. \\
\hline Anne Weying & : Hospital. Right now. \\
\hline Eddie Brock & : I can't go with you. It's not safe. \\
\hline ANNE & : He's Talking to you? \\
\hline EDDIE & : Always. \\
\hline ANNE & : Are you in pain? \\
\hline EDDIE & $\begin{array}{l}\text { : No, I don't fell anything, actually, apart from... I'm } \\
\text { hungry all the time. }\end{array}$ \\
\hline VENOM & $\begin{array}{l}\text { : And you feel sad, do you not, Eddie, when you are } \\
\text { with her? }\end{array}$ \\
\hline EDDIE & : Get out of my head, man. \\
\hline VENOM & $\begin{array}{l}\text { : You never apologized. You might not live to get } \\
\text { another chance. }\end{array}$ \\
\hline EDDIE & $\begin{array}{l}\text { : Annie. I just want to say that whatever happens, that I } \\
\text { am truly sorry for whatever ... }\end{array}$ \\
\hline
\end{tabular}


And everything I have ever done to you. I am truly, truly sorry. And that I love you.

ANNE

: Oh Eddie... Now's really not the time. Let's just keep

$(01.08 .16)$ you alive, okay?

\subsubsection{Kindness}

Eddie Brock is also a kind man. He is fond of helping people who need his help. Eddie Brock's personality as a kind journalist can also be seen in the following scripts. The scripts show the time when Eddie Brock meets mrs. Chen to buy food for him. He sees a robber who is trying to threaten Mrs. Chen with a gun. Then, Eddie Brock comes and meets this criminal and eventually in the form of venom, Brock eats him alive . This shows that Eddie Brock has a pretty good personality because he cares about other people who need his help. It is obvious in the following texts.

\begin{tabular}{|c|c|}
\hline MAN & : The payment's due, Chen \\
\hline MRS. CHEN & : Please. I can't keep doing this. \\
\hline MAN & : Now. \\
\hline VENOM & : Bad guy, right? \\
\hline Eddie Brock & : Yep. \\
\hline \multicolumn{2}{|c|}{ (FEET STOMPING) } \\
\hline VENOM/EDDIE & $\begin{array}{l}\text { : You come in here again... In Fact, you go } \\
\text { anywhere in this city, preying on innocent } \\
\text { people, and we will find you and eat both your } \\
\text { arms and then both of your legs. }\end{array}$ \\
\hline MAN & : No, no. \\
\hline VENOM/EDDIE & $\begin{array}{l}\text { : And then we will eat your face right off your } \\
\text { head. Do you understand? }\end{array}$ \\
\hline MAN & : Please... \\
\hline VENOM/EDDIE & $\begin{array}{l}\text { : Yes. So you will be this armless, legless, } \\
\text { faceless thing, won't you. Rolling down the } \\
\text { street, like a turd in the wind? }\end{array}$ \\
\hline MAN & : Do you feel me? \\
\hline & What the hell are you? \\
\hline VENOM/Eddie & : We are Venom. \\
\hline MAN & : On second thought... Please. \\
\hline
\end{tabular}

\subsection{As Venom}

One day, Eddie finds something that Dr. Carlton is hiding. That something is a symbiote, an organic cell from another world which is one of the experimental materials from the Life Foundation. Symbiote is a kind of parasite that will stick to the body it has. The symbiote, is named Venom, merged with Eddie's body. The symbiote exerts tremendous power and makes him a superhuman. Venom makes him become strong, brave and evil.

\subsubsection{Strength}

Eddie Brock has a strong personality when he becomes venom. It can be seen in the scripts of the movie when he is about to come out of the building he is trying to say 
that he does not want to fight the FBI who are going to arrest him. But the FBI group still insists on arresting Eddie Brock. Because of this, finally Eddie changes his form to Venom. He becomes a strong creature.

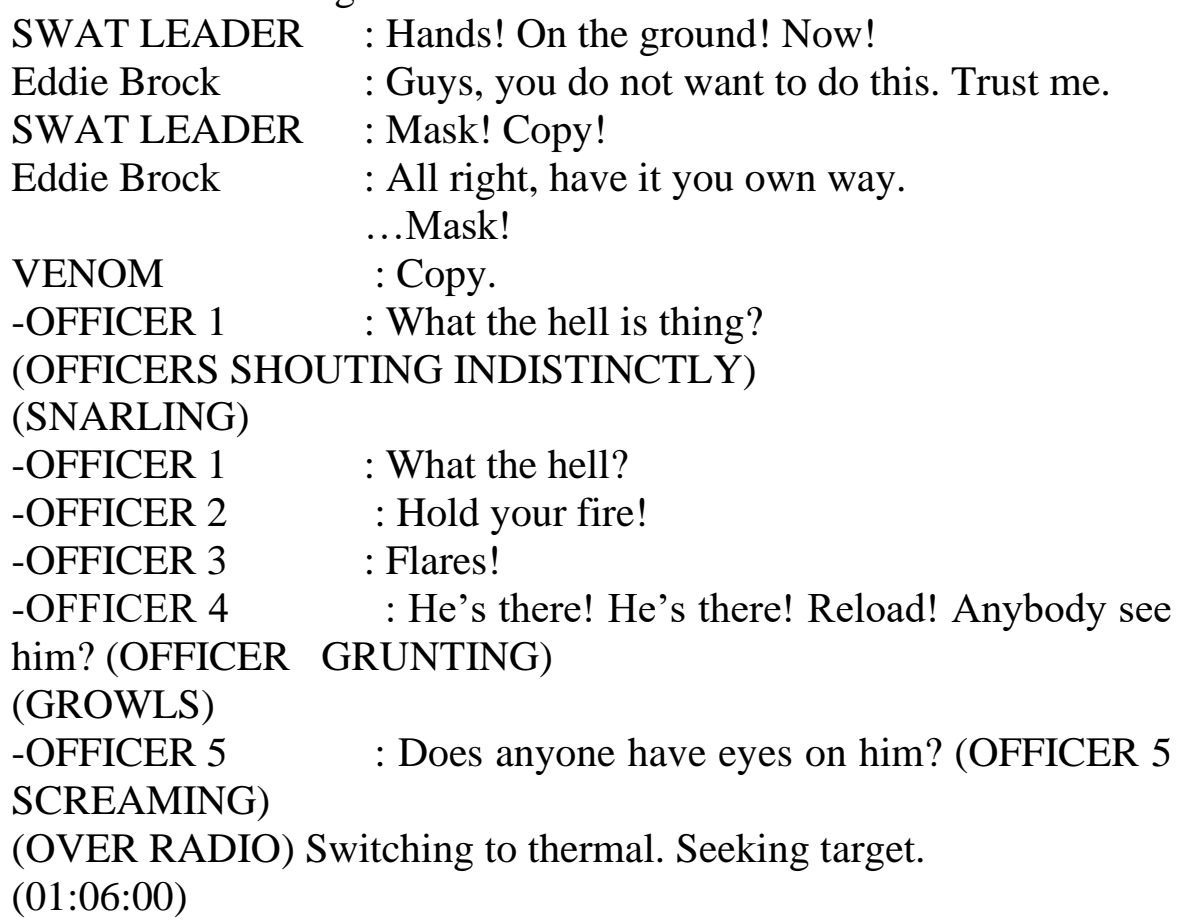

The following scripts show that Eddie Brock who becomes Venom is strong even though he could actually loses against Cartlon Drake who changes his form into Riot, but Eddie Brock / Venom still tries to fight Cartlon Drake / Riot, so they fail their attempt to destroy the contents of the earth.

\begin{tabular}{|c|c|}
\hline \multicolumn{2}{|l|}{ RIOT/DRAKE } \\
\hline \multicolumn{2}{|c|}{ AUTOMATED VOCE : T-minus two minutes, 30 seconds.- } \\
\hline VENOM & : Eddie. \\
\hline EDDIE & : Drake, stop! \\
\hline (GROWLS) & (HIGH-PITCHED \\
\hline \multicolumn{2}{|c|}{ (STRAINED GRUNTING) (FEEDBACK RINGING) } \\
\hline \multicolumn{2}{|c|}{$\begin{array}{l}\text { ANNE WEYING : Told you I could fight ugly. } \\
\text { (HIGH-PITCHED RINGING CONTINUES) }\end{array}$} \\
\hline \multicolumn{2}{|c|}{-AUTOMATED VOICE $\quad$ : T-minus one minutes- } \\
\hline DRAKE & $\begin{array}{l}\text { : You're too late. This is the next } \\
\text { (WATER SPLASHES) }\end{array}$ \\
\hline DDIE & : You talk too much. (STIFLED GAS \\
\hline
\end{tabular}

\subsubsection{Bravery}

Brave is another personality of Eddie Brock when he becomes venom. He does not feel fearful about anything. He faces all the obstacles in front of him. It is proved when Eddie Brock transforms himself into venom. He sees Cartoon Drake become Riot trying to get into the sky and aiming to destroy the universe. Eddie Brock tries to block 
Drake from fighting and destroys the rocket. They are about to climb into space. And finally Cartlon Drake/ Riot's goal fails. This shows that Eddie Brock has a brave character against Cartlon Drake even though Eddie / Venom will lose against Cartlon Drake / Riot. It is obvious in the following scripts.

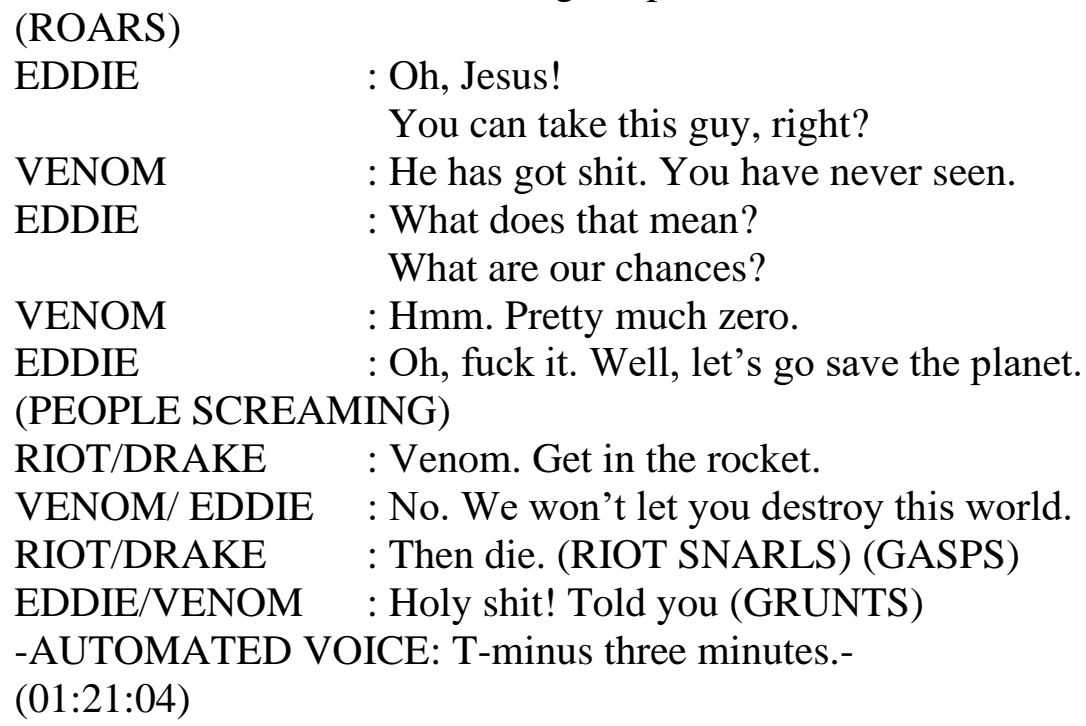

\subsubsection{Evil}

Eddie also becomes evil when he is transformed into venom. The below scripts show when Eddie Brock is hit by Treece, Cartlon Drake's guards; Brock fights them. Eddie then eats their heads without guilt and at that time, he also beats up Cartlon Drake's people wildly. Eddie Brock turns into a bad guy when he becomes Venom.

TREECE : You have been s serious pain in the ass for me, Eddie.

(STRAINED)

EDDIE : Well, you know, I am to please.

VENOM : Eyes, lungs, pancreas. So many snacks, so little time.

-(SLURPING) (GRUNTING) (GUNSHOT) (THUDS) (TREECE

GRUNTS)-

OFFICER : SFPD. Don't move! Get off the car!

-(TIRES SQUEALING) (OFFICER INDISTINCTLY) (GROANS)-

EDDIE : My leg. Oh my God, my legs were broken.

What is happening?

(SIGHS)

EDDIE : (WHISPERS) What the hell are you?

VENOM : I am Venom. And you are mine.

EDDIE : You bit somebody's head off.

(58.00)

\section{Conclusion}

Based on the analysis of Multiple Personality in Venom Movie, some conclusions are drawn:

1. Eddie Brock is actually an ordinary person who works as a journalist.

2. Venom is a kind of symbiote.

3. As a journalist, he has three personalities: weak, afraid and kind.

4. As venom, he has also three personalities: strong, brave and evil. 
5. The personalities that Eddie Brock has when he is a journalist are opposite to the ones he has when he is a venom.

\section{References}

Endraswara, Suwardi. (2003). Metodologi penilitian sastra. Yogyakarta: Pustaka Widyatama.

Funder, D. C. (1997). The personality puzzle. Riverside: University of California.

Freud, Sigmund. (1994). Pengantar Umum Personality. Yogyakarta: pustaka Pelajar.

Lundberg, Shell. (2010). Personality. Oxford: Oxford University Press.

Minderop, Albertine. (2013). Psikologi sastra. Karya Sastra, Metode, Teori, dan Contoh Kasus. Jakarta: Yayasan Pustaka Obor Indonesia.

Pinker, Jeff, et.al. (2018). Venom. California: Columbia Press.

Rob and Carolyn Spring. (2010). An Introduction to Dissociative and Dissociative Identity Disorder. PROGRESSIVE VOL XI. No. 2 September 2016. http://www.pods-online.org.uk/introtodid.html.

Smith, E. Ronald. (2004). Conceptualizing personality as a cognitiv-affective processing system. United state: University of Washington Seattle.

Walter, et.al. (2004). Personality and Assessment. New York: Willey

Widuri, Davidson \& Neale, Fausiah. (2006). Psikologi Abnormal: Klinis Dewasa. Jakarta: UI-Press 